\title{
Recent Extreme Precipitation and Temperature Changes in Djibouti City (1966-2011)
}

\author{
Pierre Ozer ${ }^{1}$ and Ayan Mahamoud ${ }^{2}$ \\ ${ }^{1}$ Department of Environmental Sciences and Management, University of Liège, Avenue de Longwy 185, 6700 Arlon, Belgium \\ ${ }^{2}$ Research Center, Department of Geomatics and Environmental Sciences, University of Djibouti, Avenue Georges Clemenceau, \\ BP 1904, Djibouti \\ Correspondence should be addressed to Pierre Ozer; pierre.ozer@gmail.com
}

Received 21 March 2013; Accepted 3 October 2013

Academic Editors: A. V. Eliseev, S. Feng, P. Gober, and S. Gualdi

\begin{abstract}
Copyright (C) 2013 P. Ozer and A. Mahamoud. This is an open access article distributed under the Creative Commons Attribution License, which permits unrestricted use, distribution, and reproduction in any medium, provided the original work is properly cited.

A dataset of 23 derived indicators has been compiled to clarify whether the frequency of rainfall and temperature extremes has changed over the last decades in Djibouti City, eastern Africa. Results show that all precipitation indices have declined over the last decades, although only the very wet day frequency and the very wet day proportion present a significant decline. Annual total precipitation has decreased by $17.4 \%$ per decade from 1980 to 2011 and recent mean yearly rainfall ( 44 mm on average from 2007 to 2011 ) meets a $73 \%$ deficit compared to the 30 -year (1981-2010) average (164 mm). The average temperature increase is $+0.28^{\circ} \mathrm{C}$ per decade. Extremely warm days (maximum temperature $\geq 45.0^{\circ} \mathrm{C}$ ) have become 15 times more frequent than in the past while extremely cool nights (minimum temperature $\leq 8.6^{\circ} \mathrm{C}$ ) have almost disappeared. Current rainfall shortages and increasing temperature extremes are impacting local people who urgently need adaptation strategies.
\end{abstract}

\section{Introduction}

Warming of the climate system is unequivocal, as is now evident from observations of increases in global average air and ocean temperatures, widespread melting of snow and ice and rising global average sea level [1].

According to the Climate Research Unit of the University of East Anglia [2], global air temperature during the period $2001-2010\left(0.48^{\circ} \mathrm{C}\right.$ above $1961-1990$ mean $)$ was $0.22^{\circ} \mathrm{C}$ warmer than that in the $1991-2000$ decade $\left(0.27^{\circ} \mathrm{C}\right.$ above 1961-1990 mean). The warmest year of the entire series (18502012) was 2010 , with a temperature of $0.54^{\circ} \mathrm{C}$ above the 19611990 mean. After 2010, the next ten warmest years in the series are all in the period 1998-2012. Most of the observed increase in global average temperatures since the mid-20th century is very likely due to the observed increase in anthropogenic greenhouse gases (GHGs) concentrations [1].

Some extreme weather events have received increased attention in the last few years within the perspective of climate change. Studies show that they have changed in frequency and/or intensity over the last 50 years. Yet, it is very likely that cold days, cold nights, and frost have become less frequent over most land areas, while hot days and hot nights have become more frequent. It is also likely that heatwaves have become more frequent and that the frequency of heavy precipitation events (or proportion of total rainfall from heavy falls) has increased over most areas [1].

In addition to the climate change impacts, population and infrastructure continue to develop in areas that are vulnerable to extremes such as flooding, storm damage, and extreme temperatures. Furthermore, land use change can often further increase vulnerability by creating more potential for catastrophic impacts from climate extremes, such as flooding due to extreme precipitation events.

Although the frequency, the intensity, and the impacts of extreme weather events are well documented in most parts of the world, there has been paucity of information on trends in daily extreme rainfall events in Africa [3]. The lack of longterm daily climate data suitable for analysis of extremes is the biggest obstacle to quantifying whether extreme events have changed over the last decades, either continental or on a more regional basis [4]. 


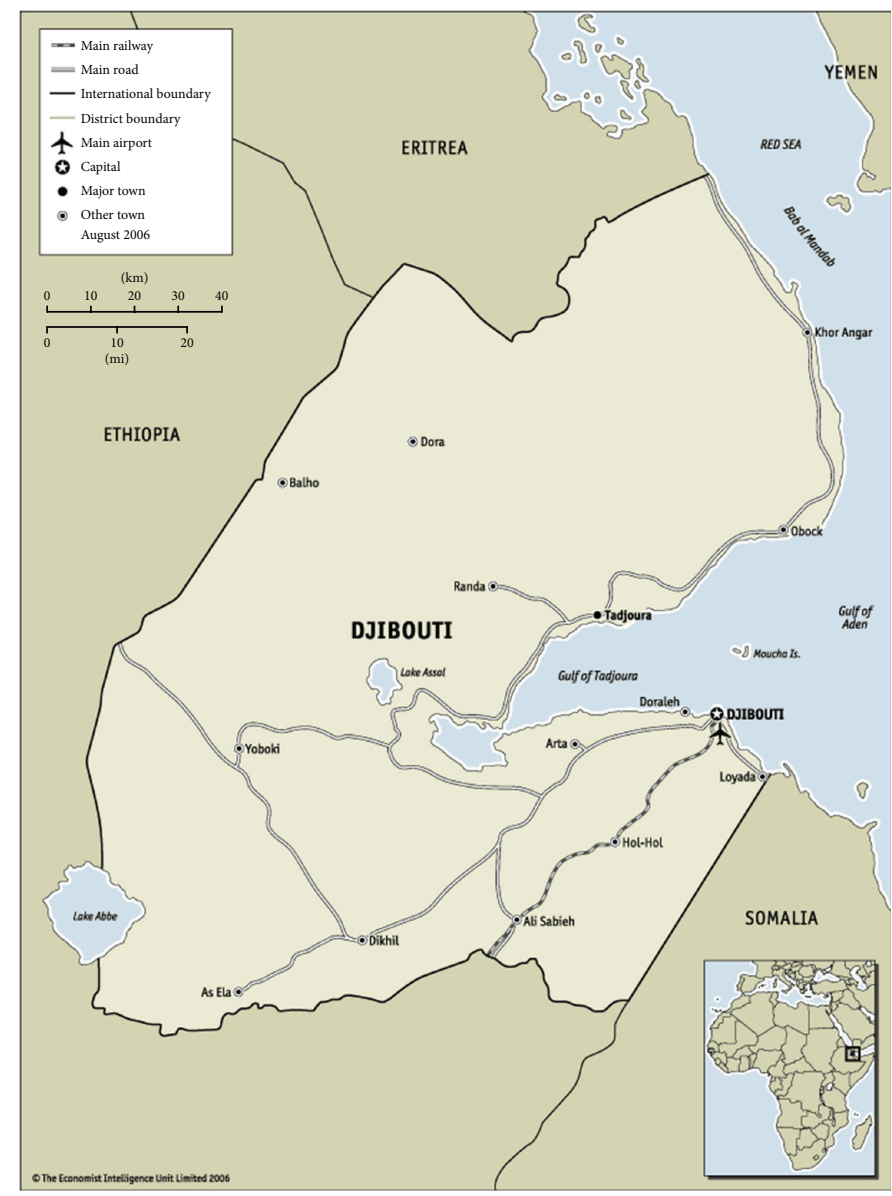

FIgure 1: Location of the Republic of Djibouti and Djibouti City.

In this paper, evidence for changes in the intensity of extreme daily rainfall and temperature events during the last decades is assessed in the Republic of Djibouti, the smallest country in the Horn of Africa bordered by Eritrea in the north, Ethiopia in the west and south, Somalia in the southeast, and facing the Red Sea and the Gulf of Aden at the east. The country occupies a total area of about $23,200 \mathrm{~km}^{2}$ (Figure 1).

According to the Köppen-Geiger world climate classification, the climate of the Republic of Djibouti is defined as a hot desert (BWh) [5]. Hot conditions prevail year-round with monthly average temperatures ranging from $25.4^{\circ} \mathrm{C}$ in January to $36.8^{\circ} \mathrm{C}$ in July, while rainfall are very scarce all year-long with monthly total precipitation below $10 \mathrm{~mm}$ from May to August and between 10 and $28 \mathrm{~mm}$ the rest of the year (Figure 2). As in many arid regions, annual rainfall is significantly irregular and extreme rainfall can be observed in a number of years [6]. We use here meteorological data from the unique synoptic station of the country, Djibouti airport, located south of the capital city of Djibouti City (Figure 1).

\section{Data and Methods}

2.1. Database. For the analysis of recent trends of extreme precipitation and temperatures, data were made available for

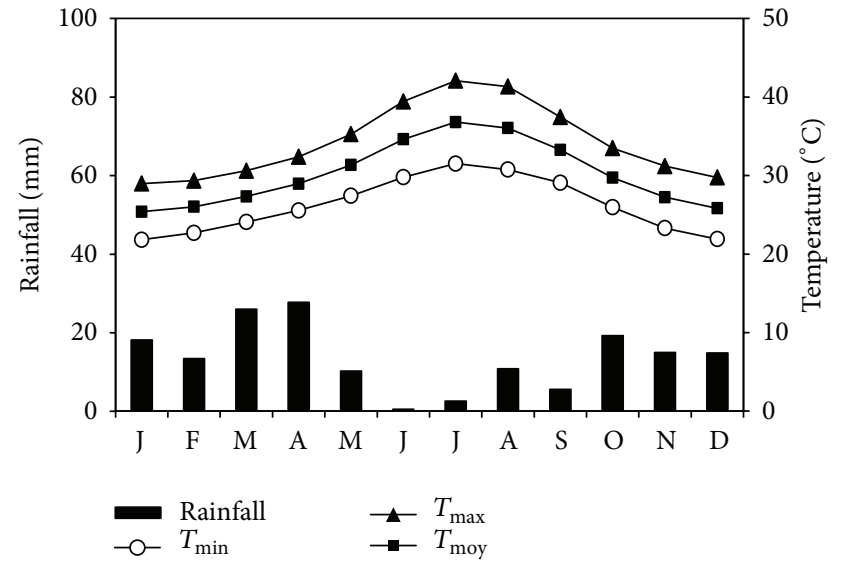

Figure 2: Monthly distribution of rainfall and temperature in Djibouti City (average 1981-2010).

the synoptic station of Djibouti City (Lat: $11.55^{\circ} \mathrm{N}$; Long: $43.15^{\circ} \mathrm{E}$; altitude: $13 \mathrm{~m}$ asl, WMO station code: 63125 ) located near the International Airport of Djibouti from the "Agence Nationale de la Météorologie (ANM) de Djibouti." The airport is located outside and south of the capital city. The database includes daily precipitation data from January 1980 
TABLE 1: Rainfall and temperature indices with their definitions and units.

\begin{tabular}{|c|c|c|c|}
\hline ID & Indicator name & Definition & Unit \\
\hline PTOT & Precipitation total & Annual total precipitation & $\mathrm{mm}$ \\
\hline $\mathrm{Rd}$ & Rainfall days & Annual total of wet days (rainfall $\geq 1 \mathrm{~mm}$ ) & days \\
\hline SDII & Simple day intensity index & Average rainfall from wet days & $\mathrm{mm} /$ day \\
\hline Rxld & Maximum 1-day rainfall & Annual maximum 1-day rainfall & $\mathrm{mm}$ \\
\hline $\mathrm{R} 10 \mathrm{~mm}$ & Number of heavy precipitation days & Annual count of days when rainfall $\geq 10 \mathrm{~mm}$ & days \\
\hline $\mathrm{R} 20 \mathrm{~mm}$ & Number of very heavy precipitation days & Annual count of days when rainfall $\geq 20 \mathrm{~mm}$ & days \\
\hline R95p & Very wet day frequency & $\begin{array}{l}\text { Annual count of days when rainfall } \geq 95 \text { th percentile of } \\
\qquad 1981-2010\end{array}$ & days \\
\hline R99p & Extreme rainfall frequency & $\begin{array}{l}\text { Annual count of days when rainfall } \geq 99 \text { th percentile of } \\
\qquad 1981-2010\end{array}$ & days \\
\hline R95pSUM & Very wet day intensity & $\begin{array}{l}\text { Annual precipitation from days when rainfall } \geq 95 \text { th } \\
\text { percentile of } 1981-2010\end{array}$ & $\mathrm{~mm}$ \\
\hline R99pSUM & Extreme rainfall intensity & $\begin{array}{l}\text { Annual precipitation from days when rainfall } \geq 99 \text { th } \\
\text { percentile of } 1981-2010\end{array}$ & $\mathrm{~mm}$ \\
\hline R95pTOT & Very wet day proportion & $\begin{array}{l}\text { Percentage of annual precipitation from days when } \\
\text { rainfall } \geq 95 \text { th percentile of 1981-2010 }\end{array}$ & $\%$ \\
\hline R99pTOT & Extreme rainfall proportion & $\begin{array}{l}\text { Percentage of annual precipitation from days when } \\
\text { rainfall } \geq 99 \text { th percentile of } 1981-2010\end{array}$ & $\%$ \\
\hline ATN & Average annual $T_{\min }$ & Annual average value of daily minimum temperature & ${ }^{\circ} \mathrm{C}$ \\
\hline ATX & Average annual $T_{\max }$ & Annual average value of daily maximum temperature & ${ }^{\circ} \mathrm{C}$ \\
\hline ATM & Average annual $T_{\text {mean }}$ & Annual average value of daily mean temperature & ${ }^{\circ} \mathrm{C}$ \\
\hline TN1p & Extreme cool night & $\begin{array}{l}\text { Annual count of days when } T_{\min } \leq 1 \text { th percentile of } \\
\qquad 1971-2000\left(18.6^{\circ} \mathrm{C}\right)\end{array}$ & days \\
\hline TN5p & Cool night & $\begin{array}{l}\text { Annual count of days when } T_{\min } \leq 5 \text { th percentile of } \\
1971-2000\left(20.2^{\circ} \mathrm{C}\right)\end{array}$ & days \\
\hline TN95p & Warm night & $\begin{array}{l}\text { Annual count of days when } T_{\min } \geq 95 \text { th percentile of } \\
\qquad 1971-2000\left(32.2^{\circ} \mathrm{C}\right)\end{array}$ & days \\
\hline TN99p & Extreme warm night & $\begin{array}{l}\text { Annual count of days when } T_{\min } \geq 99 \text { th percentile of } \\
\qquad 1971-2000\left(33.6^{\circ} \mathrm{C}\right)\end{array}$ & days \\
\hline TXlp & Extreme cool day & $\begin{array}{l}\text { Annual count of days when } T_{\max } \leq 1 \text { th percentile of } \\
\qquad 1971-2000\left(27.5^{\circ} \mathrm{C}\right)\end{array}$ & days \\
\hline TX5p & Cool day & $\begin{array}{l}\text { Annual count of days when } T_{\max } \leq 5 \text { th percentile of } \\
\qquad 1971-2000\left(28.5^{\circ} \mathrm{C}\right)\end{array}$ & days \\
\hline TX95p & Warm day & $\begin{array}{l}\text { Annual count of days when } T_{\max } \geq 95 \text { th percentile of } \\
\qquad 1971-2000\left(43.9^{\circ} \mathrm{C}\right)\end{array}$ & days \\
\hline TX99p & Extreme warm day & $\begin{array}{l}\text { Annual count of days when } T_{\max } \geq 99 \text { th percentile of } \\
1971-2000\left(45.0^{\circ} \mathrm{C}\right)\end{array}$ & days \\
\hline
\end{tabular}

to December 2011 and maximum, minimum, and mean daily temperatures from January 1966 to December 2011. There were no missing data, so the database can be used for trend analysis [7].

2.2. Extreme Rainfall Indices. In this study, 12 rainfall indices were calculated over the January to December period and are listed in Table 1. These are the annual total precipitation (PTOT), the annual total of wet days (with daily rainfall $\geq 1 \mathrm{~mm}, \mathrm{Rd}$ ), the simple day intensity index (SDII) that was calculated as the average rainfall from wet days, the annual maximum rainfall recorded during 1 day (Rxld), and the number of heavy precipitation (rainfall $\geq 10 \mathrm{~mm}, \mathrm{R} 10 \mathrm{~mm}$ ) and very heavy precipitation (rainfall $\geq 20 \mathrm{~mm}, \mathrm{R} 20 \mathrm{~mm}$ ) days. Other six indices are based on the 95th and 99th percentiles which define a very wet day and an extreme rainfall event, respectively [7-13]. These percentile values were calculated from daily rainfall data over the 1981-2010 period. For the station of Djibouti City, the thresholds calculated from percentiles are $46.9 \mathrm{~mm}$ and $108.1 \mathrm{~mm}$ to define a very wet day and an extreme rainfall event, respectively. Based on these percentiles, two extreme precipitation indices were chosen. Very wet day and extreme rainfall frequency are based on the annual count of days when rainfall $\geq 95$ th and 99th percentiles of 1981-2010 (R95p and R99p). Very wet day and extreme rainfall intensity correspond to the annual total precipitation recorded from days when rainfall $\geq 95$ th and 99th percentiles of 1981-2010 (R95pSUM and R99pSUM) and give an indication on the rain received from very wet or extreme rainfall. Very wet day and extreme rainfall proportion are the percentage of the annual total 


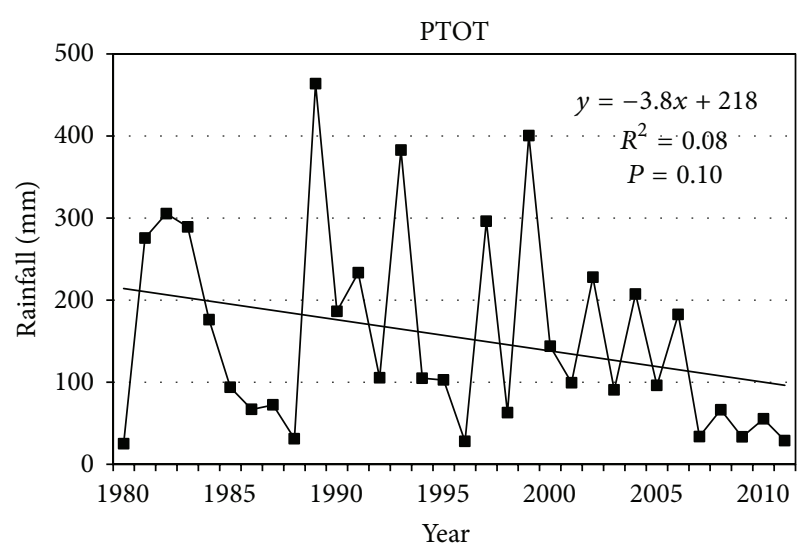

(a)

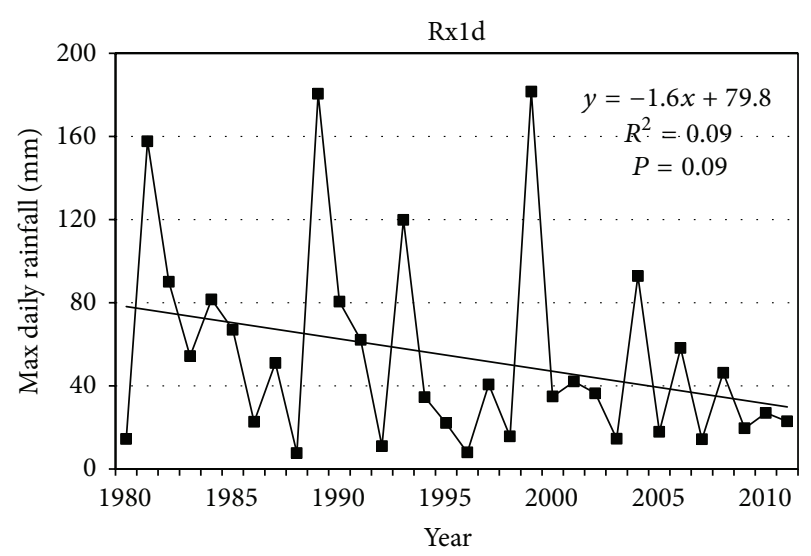

(c)

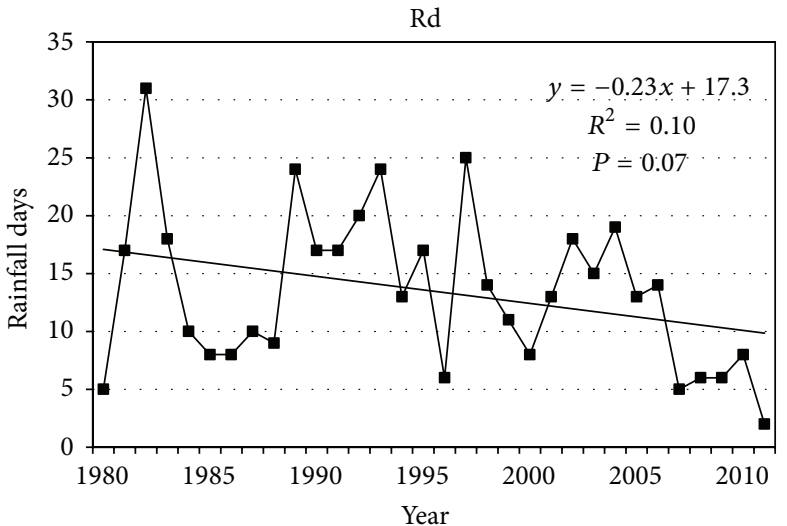

(b)

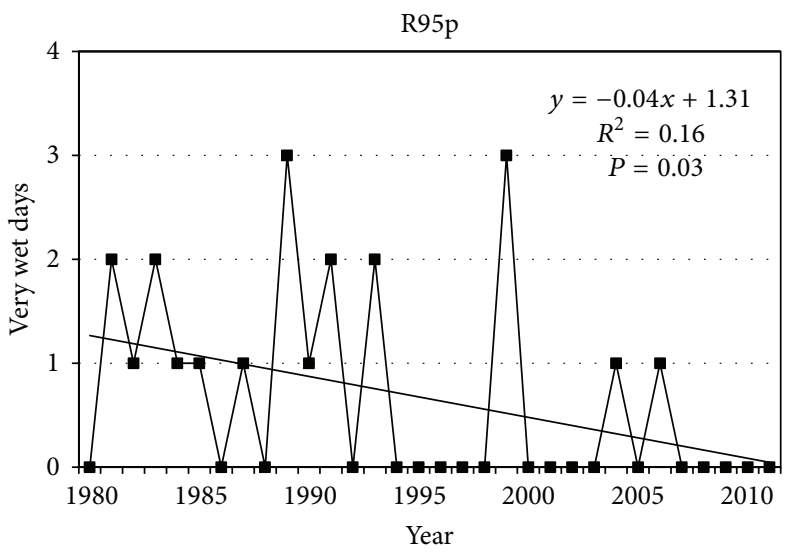

(d)

Figure 3: Evolution and trends of PTOT, Rd, Rxld, and R95p in Djibouti City (1980-2011).

precipitation recorded from days when rainfall $\geq 95$ th and 99th percentiles of 1981-2010 (R95pTOT and R99pTOT) and measure how much total rain comes from very wet or extreme events.

2.3. Extreme Temperature Indices. The analysis of minimum, maximum, and mean temperatures is based on 11 indices calculated over the January to December period (Table 1). Three of them are based on the annual average value of daily minimum, maximum, and mean temperatures (ATN, ATX, and ATM) in order to analyse the global trends in temperatures. All other indices are based on the 1st, 5th, 95th, and 99th percentiles which define "extremely cool," "cool," "warm," and "extremely warm" nights (using $T_{\min }$ ) and days (using $T_{\max }$ ), respectively, (adapted from [10-13]). These percentile values were calculated from daily rainfall data over the 19712000 period. Threshold temperature values calculated from percentiles are presented in Table 1. In Djibouti, an extremely cool night is characterized by minimum temperatures $\leq 8.6^{\circ} \mathrm{C}$ while an extremely warm day is defined when maximum temperatures are $\geq 45.0^{\circ} \mathrm{C}$.

2.4. Trend Analysis. In the analysis, trend coefficients are determined using linear regression modelling, which represent the increasing or decreasing rate of the given index during 1980-2011 period for precipitation and 1966-2011 period for temperatures. This method is now extensively used worldwide [7-13]. Each slope (positive or negative) was categorized in six classes indicating very significant, significant, or nonsignificant trends. The regression procedure supplies a Student $t$-test and its resulting significance $P$ level to analyse the hypothesis that the slope is equal to 0 . This $P$-level was used as a criterion to define the class boundaries. The trends, for each index, were labelled as "very significant" if the $P$ level exceeded 0.01 for the one-tailed $t$-test, "significant" if the $P$-level ranged between 0.01 and 0.05 , and otherwise "nonsignificant" if the $P$-level is up to 0.05 .

\section{Results}

3.1. Precipitation. Time series of several precipitation indices can be seen in Figure 3. All indices show decreasing trends although most of them are statistically nonsignificant (Table 2). Yet, the annual total precipitation (PTOT), the rainfall days (Rd), the annual maximum rainfall recorded during 1 day (Rxld), and the very wet day rainfall intensity (R95pSUM) decrease in a moderate way. Only the very wet day frequency (R95p) and the very wet day proportion (R95pTOT) present a significant decline. It is likely that 
TABLE 2: Rainfall trends analysis from 1980 to 2011.

\begin{tabular}{lccccc}
\hline ID & Unit & $\begin{array}{c}\text { Average } \\
1981-2010\end{array}$ & $\begin{array}{c}\text { Trend } \\
\text { units/decade }\end{array}$ & $\begin{array}{c}\text { Significance } \\
(P \text { level })\end{array}$ & $\begin{array}{c}\text { Trend } \\
\% / \text { decade }\end{array}$ \\
\hline PTOT & mm & 164 & -38.0 & 0.10 & -17.4 \\
Rd & days & 14.1 & -2.3 & 0.07 & 0.70 \\
SDII & mm/day & 11.1 & -0.5 & 0.09 & -13.5 \\
Rxld & mm & 56.4 & -15.6 & 0.38 & -19.5 \\
R10 mm & days & 3.9 & -0.5 & 0.27 & -10.7 \\
R20 mm & days & 2.1 & -0.5 & 0.03 & -16.7 \\
R95p & days & 0.70 & -0.39 & 0.26 & -30.2 \\
R99p & days & 0.13 & -0.07 & 0.07 & -29.7 \\
R95pSUM & mm & 59.7 & -31.4 & 0.28 & -29.1 \\
R99pSUM & mm & 21.3 & -11.5 & $<.01$ & -31.3 \\
R95pTOT & $\%$ & 23.4 & -14.2 & -3.7 & 0.20 \\
R99pTOT & $\%$ & 5.8 & -32.1 \\
\hline
\end{tabular}

the extreme rainfall events (R99p) decline may be significant but it is difficult to make statistics on such a limited sample.

The most significant rainfall shortage is found over the last five years (see Figure 3). Yet, since 2007, the yearly rainfall average has been $44 \mathrm{~mm}$, which is an extreme rainfall deficit of near 75\% when compared to the 1981-2010 average $(164 \mathrm{~mm})$. During this same recent period, the synoptic station of Djibouti City did not record any extreme rainfall nor very wet day events. The maximum rainfall recorded during 1 day was $46 \mathrm{~mm}$ over the last five years.

These data are of the highest importance in terms of vulnerability evolution as well as future adaptation strategies to natural hazard reduction, especially concerning floods. This aspect will be discussed afterwards.

3.2. Temperature. The analysis of the annual time series of the temperature indices indicates that changes in temperature extremes over the 1966-2011 period reflect warming for the Djibouti City area. The trends in annual average minimum, maximum, and mean temperatures (ATN, ATX, and ATM) presented in Figure 4 and given in Table 3 show a very significant increase of the three indices. Mean temperature increased by $1.24^{\circ} \mathrm{C}\left(0.28^{\circ} \mathrm{C}\right.$ per decade $)$ during the $1966-2011$ period. The warmest year of the entire series was 2010 with mean temperature of $31.3^{\circ} \mathrm{C}$, which is $1.18^{\circ} \mathrm{C}$ above the $1971-$ 2000 mean. The ten warmest years of the whole record have been registered since 1998. The period 2001-2011 was $0.66^{\circ} \mathrm{C}$ warmer than the 1971-2000 mean (Table 3).

The annual number of warm and extremely warm days and nights, analyzed through the TX95p, TX99p, TN95p, and TN99p indices, has significantly increased. Extremely warm days and nights were 11.5 and 13.3 on average during 20012011, a much higher figure than the averages of 4.7 and 3.8 recorded during the 1971-2000 reference period (Table 3). Conversely, the number of cool and extremely cool nights and days, analyzed through TN5p, TN1p, TX5p, and TX1p, has decreased significantly. Trends of extremes are shown in Figure 4.

\section{Discussion}

Lack of long-term climate data suitable for analysis of extremes is the biggest obstacle to quantifying whether extreme events have changed over the last decades in Africa. This paper presents, for the first time, the analysis of extreme precipitation and temperatures in Djibouti City.

Results show that all rainfall indices have declined over the last 32 years, although only the very wet day frequency (R95p) and the very wet day proportion (R95pTOT) present a significant decline. Such recent decrease in annual total precipitation (PTOT) is in line with recent findings in the Arab region [12], over the Great Horn of Africa region [13], in the Arabian Peninsula [14], or in Ethiopia [15] and is likely to be increasingly influenced by the Indian Ocean sea surface temperature [16]. In terms of all other rainfall indices, a mainly nonsignificant decreasing trend is observed that may suggest a consistent change towards drier conditions as emphasized in the northern part of the Great Horn of Africa [13] and in the eastern part of the Arab region [12].

All trends of temperature indices indicate serious significant warming in Djibouti City. Mean temperature increased by $1.24^{\circ} \mathrm{C}$ during the $1966-2011$ period and the period $2001-$ 2011 was $0.66^{\circ} \mathrm{C}$ warmer than the $1971-2000$ mean. This increase in temperature is much higher than the global warming [2] and is fully consistent with other studies carried out in the Arab region [12], over the Great Horn of Africa region [13], in the Arabian Peninsula [14], or in Sudan [17]. Extremely warm days characterized by daily maximum temperatures $\geq 45^{\circ} \mathrm{C}$ have become 15 times more frequent than in the past (comparing the decades 1966-75 and 20022011 periods) while extremely cool nights $\left(<18.7^{\circ} \mathrm{C}\right)$ have almost disappeared. These impressive changes are observed at the global level [1] and are very significant in our region of interest $[12,13]$. 


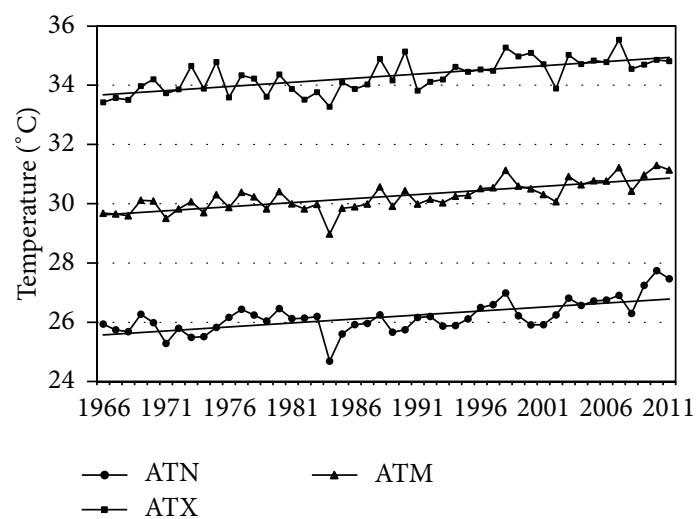

(a)

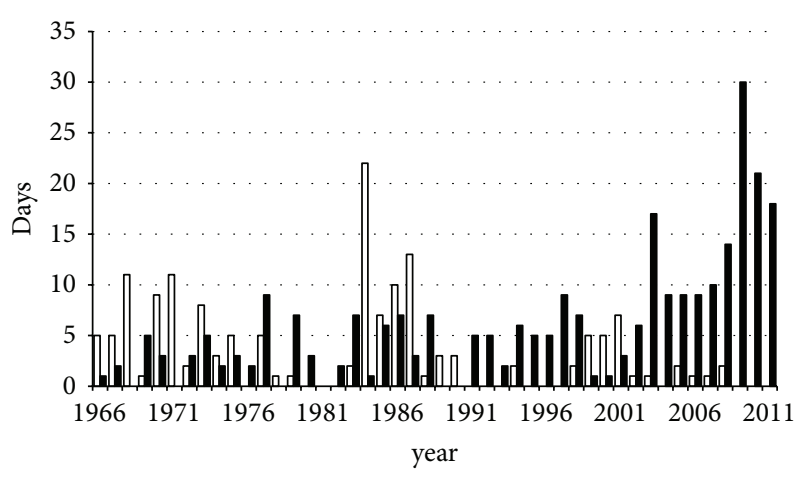

$\square$ TN1p

- TN99p

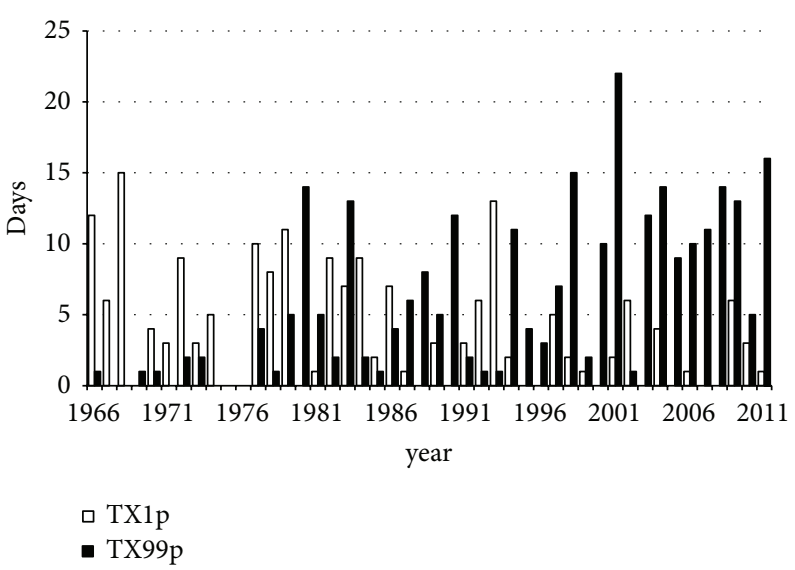

(c)

Figure 4: Evolution of (a) ATN, ATX, and ATM; (b) extremely cool (TN1p) and warm (TN99p) nights; and (c) extremely cool (TX1p) and warm (TX99p) days in Djibouti City (1966-2011).

TABLE 3: Temperature trends analysis from 1966 to 2011 and averages calculated for the 1971-2000 and 2001-2011 periods.

\begin{tabular}{|c|c|c|c|c|c|}
\hline ID & Unit & $\begin{array}{c}\text { Average } \\
1971-2000\end{array}$ & $\begin{array}{l}\text { Trend (1966-2011) } \\
\text { units/decade }\end{array}$ & $\begin{array}{l}\text { Significance } \\
(P \text { level })\end{array}$ & $\begin{array}{l}\text { Average } \\
\text { 2001-2011 }\end{array}$ \\
\hline ATN & ${ }^{\circ} \mathrm{C}$ & 26.0 & +0.27 & $<0.001$ & 26.8 \\
\hline ATX & ${ }^{\circ} \mathrm{C}$ & 34.2 & +0.28 & $<0.001$ & 34.8 \\
\hline ATM & ${ }^{\circ} \mathrm{C}$ & 30.1 & +0.28 & $<0.001$ & 30.8 \\
\hline TN1p & days & 3.7 & -1.2 & 0.014 & 1.4 \\
\hline TN5p & days & 19.1 & -4.8 & $<0.001$ & 9.2 \\
\hline TN95p & days & 18.8 & +6.3 & $<0.001$ & 38.3 \\
\hline TN99p & days & 3.8 & +2.8 & $<0.001$ & 13.3 \\
\hline TX1p & days & 4.0 & -1.2 & 0.005 & 2.1 \\
\hline TX5p & days & 21.9 & -9.0 & $<0.001$ & 6.6 \\
\hline TX95p & days & 19.0 & +3.8 & $<0.001$ & 28.5 \\
\hline TX99p & days & 4.7 & +2.7 & $<0.001$ & 11.5 \\
\hline
\end{tabular}

\section{Impact of Extreme Weather in Recent Years}

Since 2007, mean yearly rainfall $(44 \mathrm{~mm})$ has met a $73 \%$ deficit when compared to the 30 -year average $(164 \mathrm{~mm})$, a situation that is much worse than what was observed in the early 1980s. Yet, it has been shown that 2009 was a year of exceptionally widespread drought in Ethiopia, the second driest year ever recorded after the historic year 1984 [15]. In 2012, this period of consecutive dry year continued [18]. This impacted the well-being and, in some cases, the survival of the inhabitants of the Republic of Djibouti, especially rural population whose migration towards Djibouti City has 
increased in recent years. By the end of 2011, nearly 19 million people were declared food insecure in East Africa, among which 206,000 people are in the Republic of Djibouti: 120,000 rural, 26,000 Somalian and Ethiopian refugees, and 60,000 urban $[19,20]$.

Drought is one of the main factors of migration to Djibouti City [21]. These new informal settlements continue to grow in the south and west of the city avoiding the restrictions put by the state and may be at risk [21]. Limited access to risk knowledge may lead to settlements in riskprone areas. Yet, the maximum daily rainfall recorded over those last five years was $46 \mathrm{~mm}$ in 2008. But we showed here that extreme daily rainfall events are characterized by an amount over $108 \mathrm{~mm}$. In addition, it has been reported that the maximum rainfall recorded during 1 day reached $211 \mathrm{~mm}$ in Djibouti City [22]. Such rainfall occurred in the past, and they will occur in the future. In addition, the fourth IPCC report states that precipitation extremes are projected to increase worldwide independently of the trend in annual total precipitation [1]. Uncontrolled urbanization process may turn into catastrophic hazard in case of heavy rainfall as it has been seen elsewhere in arid zones of Africa [23-26]. The latest dramatic flood that impacted Djibouti occurred in 2004. It has been estimated that approximately 300 people died; 600 houses were destroyed and other 100 ones were inundated; 3,000 persons were made homeless; and the lives of a total of 100,000 persons were affected [27]. But the country also experienced killing floods in 1981, 1989, and 1994, systematically affecting over 100,000 people [28]. The risk of flooding is therefore real. Moreover, since the rainfall decline in the Greater Horn of Africa is influenced by the warming of the southern tropical Indian Ocean sea surface temperature [16], it is likely that migration from rural to urban areas due to rainfall shortages will not stop nor reverse in the coming decades. Local authorities should pay special attention to this specific hazard within urban planning policies.

Large augmentation of temperature indices has been highlighted. Such increase in heatwaves clearly has an impact on human health [29]. The greater absolute burden of adverse health impact from heatwaves is in the general community, but workers in various heat exposed workplaces are particularly vulnerable. The impact is therefore also economical. Considering this increasing threat, the health sector of the Republic of Djibouti should play a central role to communicate the health risks of heatwave, to initiate studies on the real impact of such high temperatures on mortality and morbidity, and to promote, lead, and evaluate a range of adaptive strategies. On its side, the National Agency of Meteorology of Djibouti should develop a heatwave early warning system in order to alert the population when weather conditions pose risks to health as it has been done elsewhere [30].

\section{Conclusion}

Although the daily rainfall and temperature datasets over Djibouti should be extended, the analysis of climatic features recorded at the station of Djibouti City over the last decades justifies national and international concerns about the recent drought and heatwaves.

Yet, with yearly precipitation ranging between 29 and $66 \mathrm{~mm}$ between 2007 and 2011, the last 5-year period (average rainfall of $44 \mathrm{~mm}$ ) has been the driest ever recorded since 1980 with precipitation amount as low as $27 \%$ of the longterm mean (1981-2010). Such large rainfall shortages were recorded elsewhere in the neighbouring countries of the Great Horn of Africa $[15,20]$ and partly explain recent food insecurity in the country and the large migration fluxes towards Djibouti City [19-21]. The conjunction of a very dry period with the absence of extreme daily rainfall events and limited access to risk knowledge increases the settlements in flood-prone areas and contribute to flood vulnerability. Local authorities have now to challenge two rainfall related hazards: the current drought impact and the effects of future exceptional rainfalls with probable large damages in recent settlements.

With an average mean temperature of $31.0^{\circ} \mathrm{C}$, the $2007-$ 2011 period has been the hottest 5-year period ever recorded since $1966,0.9^{\circ} \mathrm{C}$ warmer than the long-term mean (19712000). Extremely warm nights and days have become much more frequent than in the past while extremely cool nights and days tend to disappear. These trends observed in the bordering countries [12-14] clearly have an impact on human health that needs to be managed by national authorities.

\section{Acknowledgments}

This paper would not be possible without the collaboration of Mr. Osman Saad and Mr. Abdourahman Youssouf from the "Agence Nationale de la Météorologie (ANM) de Djibouti" who provided meteorological data.

\section{References}

[1] IPCC, "Climate change 2007: synthesis report," in Contribution of Working Groups I, II and III To the Fourth Assessment Report of the Intergovernmental Panel on Climate Change, K. Pachauri and A. Reisinger, Eds., IPCC, Geneva, Switzerland, 2007.

[2] P. Jones, "Global temperature record," Climate Research Unit, University of East Anglia, 2013, http://www.cru.uea.ac.uk/cru/ info/warming/.

[3] M. New, B. Hewitson, D. B. Stephenson et al., "Evidence of trends in daily climate extremes over southern and West Africa," Journal of Geophysical Research, vol. 111, Article ID D14102, 11 pages, 2006.

[4] D. R. Easterling, H. F. Diaz, A. V. Douglas et al., "Longterm observations for monitoring extremes in the Americas," Climatic Change, vol. 42, no. 1, pp. 285-308, 1999.

[5] M. C. Peel, B. L. Finlayson, and T. A. McMahon, "Updated world map of the Köppen-Geiger climate classification," Hydrology and Earth System Sciences, vol. 11, no. 5, pp. 1633-1644, 2007.

[6] J. F. Griffiths, "Climates of Africa," in World Survey of Climatology, vol. 10, Elsevier Publishing, New York, NY, USA, 1972.

[7] A. M. G. Klein Tank, J. B. Wijngaard, and A. van Engelen, Climate of Europe: Assessment of Observed Daily Temperature and Precipitation Extremes, KNMI, De Bilt, Netherlands, 2002. 
[8] G. M. Griffiths, M. J. Salinger, and I. Leleu, “Trends in extreme daily rainfall across the South Pacific and relationship to the South Pacific convergence zone," International Journal of Climatology, vol. 23, no. 8, pp. 847-869, 2003.

[9] M. R. Haylock, T. C. Peterson, L. M. Alves et al., "Trends in total and extreme South American rainfall in 1960-2000 and links with sea surface temperature," Journal of Climate, vol. 19, no. 8, pp. 1490-1512, 2006.

[10] M. J. Manton, P. M. Della-Marta, M. R. Haylock et al., "Trends in extreme daily rainfall and temperature in southeast Asia and the south Pacific: 1961-1998," International Journal of Climatology, vol. 21, no. 3, pp. 269-284, 2001.

[11] E. Aguilar, T. C. Peterson, P. R. Obando et al., "Changes in precipitation and temperature extremes in Central America and northern South America, 1961-2003," Journal of Geophysical Research D, vol. 110, no. 23, Article ID D23107, pp. 1-15, 2005.

[12] M. G. Donat, T. C. Peterson, M. Brunet et al., "Changes in extreme temperature and precipitation in the Arab region: long-term trends and variability related to ENSO and NAO," International Journal of Climatology, 2013.

[13] P. A. Omondi, J. L. Awange, E. Forootan et al., "Changes in temperature and precipitation extremes over the Great Horn of Africa region from 1961 to 2010," International Journal of Climatology, 2013.

[14] M. Almazroui, M. Nazrul Islam, H. Athar, P. D. Jones, and M. A. Rahman, "Recent climate change in the Arabian Peninsula: annual rainfall and temperature analysis of Saudi Arabia for 1978-2009," International Journal of Climatology, vol. 32, no. 6, pp. 953-966, 2012.

[15] E. Viste, D. Korecha, and A. Sorteberg, "Recent drought and precipitation tendencies in Ethiopia," Theoretical and Applied Climatology, vol. 112, pp. 535-551, 2013.

[16] A. P. Williams, C. Funk, J. Michaelsen et al., "Recent summer precipitation trends in the Greater Horn of Africa and the emerging role of Indian Ocean sea surface temperature," Climate Dynamics, vol. 39, pp. 2307-2328, 2012.

[17] N. A. Elagib, "Trends in intra-and inter-annual temperature variabilities across Sudan,” Ambio, vol. 39, no. 6, pp. 413-429, 2010.

[18] ICPAC, "IGAD Climate Prediction and Applications Centre Monthly Bulletin, April 2012," Report ICPAC/02/242, 11 pages, 2012.

[19] OCHA, in Consolidated Appeal for Djibouti 2012, Office for the Coordination of Humanitarian Affairs (OCHA), United Nations, New York, NY, USA, 2011.

[20] M. V. K. Sivakumar, "Current droughts: Context and need for national drought policies," in Towards a Compendium on National Drought Policy. Proceedings of an Expert Meeting on the Preparation of a Compendium on National Drought Policy, July 14-15, 2011, Washington, DC, USA, V. K. . Sivakumar, R. P. Motha, D. A. Wilhite, and J. J. Qu, Eds., pp. 2-12, World Meteorological Organization, Geneva, Switzerland, 2011.

[21] A. S. Chiré, Le Nomade et la Ville a Djibouti: Stratégies D'Insertion Urbaine et production de Territoire, Karthala, Paris, France, 2012.

[22] M. Shahin, Water Resources and Hydrometeorology of the Arab Region, Springer, Dordrecht, The Netherlands, 2007.

[23] S. Sene and P. Ozer, "Evolution pluviométrique et relation inondations: événements pluvieux au Sénégal," Bulletin de la Société Géographique De Liège, vol. 42, pp. 27-33, 2002.

[24] A. Tarhule, "Damaging rainfall and flooding: the other Sahel hazards," Climatic Change, vol. 72, no. 3, pp. 355-377, 2005.
[25] M. A. Ould Sidi Cheikh, P. Ozer, and A. Ozer, "Flood risks in the city of Nouakchott (Mauritania)," Geo-Eco-Trop, vol. 31, no. 1, pp. 19-42, 2007.

[26] A. Maheu, "Urbanization and flood vulnerability in a periurban neighborhoodof Dakar, Senegal: How can participatory GIS contribute to flood management?" in Climate Change and the Sustainable Use of Water Resources. Climate Change Management, W. L. Filho, Ed., pp. 185-207, Springer, Berlin, Germany, 2012.

[27] W. H. O. ], Assessment Report on the April 2004 Floods, World Health Organization, Republic of Djibouti, 2004.

[28] "Djibouti: disasters statistics," 2013, http://www.preventionweb .net/.

[29] T. McMichael, H. Montgomery, and A. Costello, "Health risk, present and future, from global climate change," British Medical Journal, vol. 344, Article ID e1359, 5 pages, 2012.

[30] K. L. Ebi, T. J. Teisberg, L. S. Kalkstein, L. Robinson, and R. F. Weiher, "Heat watch/warning systems save lives: estimated costs and benefits for Philadelphia 1995-98," Bulletin of the American Meteorological Society, vol. 85, no. 8, pp. 1067-1073, 2004. 

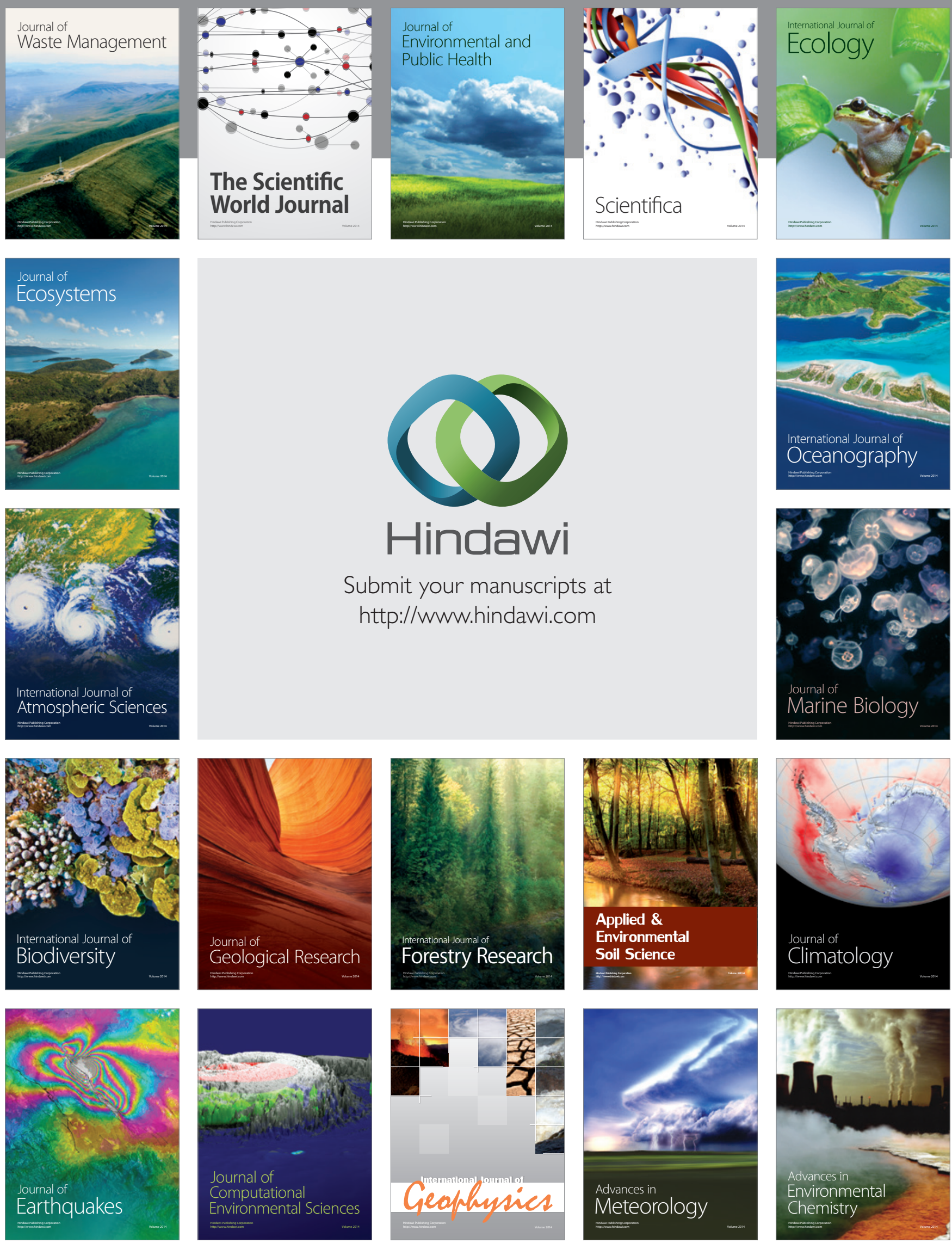